\title{
Analysis of Total Factor Productivity of Power and Energy Sector in Bangladesh: A Study on CSE Listed Companies
}

\section{Mohammad Emdad Hossain ${ }^{1}$, Md. Kazi Golam Azam², Abdullah Mohammad Ahshanul Mamun², Syed Mohammad} Hasib Ahsan ${ }^{2}$

\begin{abstract}
${ }^{1}$ Associate Professor, ${ }^{2}$ Assistant Professor, Department of business administration, Faculty of Business Studies IIUC, Bangladesh
DOI: $10.36347 /$ sjebm.2021.v08i05.002

| Received: 21.03.2021 | Accepted: 28.04.2021 | Published: 28.05.2021

*Corresponding author: Md. Kazi Golam Azam

Abstract

Original Research Article

Data envelopment analysis (DEA) is one of the most prominent productivity analysis model which measures overall performance of a firm based on specified input and output factors considering time series data. Power and energy sector of Bangladesh are controlled by both state owned and institutional ownership. The aim of the study is to assess Productivity performance of privately owned power and energy sector of Bangladesh by considering salaries and operating expenditure as input factors and revenue profit and total asset are output factors of eleven companies listed under Chittagong Stock Exchange (CSE) of Bangladesh. Malmquist output oriented productivity analysis was used to examine six years' time series data, finds that total factor productivity of power and energy sector under private ownership is increased by $2.5 \%$ indicating firms overall efficiency is increased within sample period of time. The limitation of study is that long term time series data and state owned Organization are not considered in this study. Further research may be carried out considering both state owned and privatized institutions as well as more inputoutput variables may be used to examine the effectiveness of this sector on the whole economy.

Key words: Power and energy sector, Malmquist Analysis, efficiency Change, Total Factor Productivity change, Chittagong Stock Exchange.

Copyright (C) 2021 The Author(s): This is an open-access article distributed under the terms of the Creative Commons Attribution 4.0 International License (CC BY-NC 4.0) which permits unrestricted use, distribution, and reproduction in any medium for non-commercial use provided the original author and source are credited.
\end{abstract}

\section{INTRODUCTION}

Bangladesh one of most densely populated country with more than 200 million populations mostly rely on agriculture. However, Bangladesh experienced growth of gross domestic product by $8.5 \%$ in 2019 as compared with previous year. Moreover, GDP growth rate is estimated to be dropped by 3.8 percent comparing with last year. Rapid urbanization due to natural calamity like flood, river erosion, earthquake, vulnerable temperature requires high rate of power and energy.

It is anticipated that power and energy is one of the key wheeler of growth indicators of Bangladesh economy like poverty, education, sustainable structure development and security etc. Moreover, future development depends mostly on power and energy availability in this country [1]. Consequently, energy resources like coal, oil and gas are the prime sources of fuel for electricity production. It is expected that total electricity demand in Bangladesh will be 20,000 megawatt in the year 2021. The government has adopted strategy relevant to energy development leading to supply availability that helps managing demand and wastage of resource utilization.

In Bangladesh both state owned and privately owned power and energy producing industries are producing and distributing this resources simultaneously. More than twenty companies listed in both Chittagong stock exchange (CSE) and Dhaka Stock Exchange, are working to contribute National electricity and energy production.

Nationwide research was made to measure performance and efficiency of this sector. To measure performance of this sector several studies were carried out [2] emphasizing on electricity consumption as a precondition to attain greater GDP growth, both in the long run and short run aspect for Bangladesh. However, no studies concentrated on overall performance of those firms which are working in a profit motive but generating benefits nationally.

This paper is designed to measure overall productivity performance of selected companies listed under stock exchanges of Bangladesh covering the time 
period of 2013-2019 using DEA analysis. This analysis is important as firms need to measure their own performances so that they can assess themselves in terms of efficiency. The findings of the study proclaim positive performance of this sector that will motivate business entity to participate, gaining economic profit as well as contributing towards economic development.

The residual part of the research is assembled as follows. Section 2 summarizes past research contribution in this field. Section 3 describes objectives of the study and section 4 focuses on methods and methodology of the study. Finally section 5 applies malmquist productivity index to measure efficiency change, technical efficiency, pure technical efficiency and finally total factor productivity change to the selected privately owned power and energy producing companies in Bangladesh. Abbreviations and data output from DEA are attached at the end of this paper.

\section{LITERATURE REVIEW}

We review several research works regarding productivity analysis of power and energy saving industries in the world as well as Bangladesh. Some of the literature relevant to the research on this subject has been thoroughly reviewed accordingly and summarized below:

The thesis paper aims to analyze economic condition of the electric power supply industry of Iran as well as some selected developing countries. Data of twenty six developing countries, unbalanced data of thirty distribution company as well as thirty power plant companies were selected for data analysis. Two analysis tools were used to analyze data name stochastic Frontier analysis (SFA) and malmquist index of Data envelopment analysis (DEA).To investigate technological change, technical and scale efficiency were carried on by using malmquist analysis. The findings of the study directs some different aspect, firstly, Public ownership may influence negatively influence efficiency change. Secondly, power distribution and production companies in developing countries has increase return to scale. Finally, power generation plant of individual ownership must focus on power production efficiency and distribution efficiency in order to reduce wastage of resources. In conclusion, this study kept some issue for further research such as collaboration among strong and weak companies are necessary for the sake of improving weak companies. Further investigation made conduct on allocative efficiency and its impact on ownership of the power generation and distribution companies [3].

Khatun and Ahamad, 2015 [4], scrutinized causal impact of foreign direct investment (FDI) on energy consumptions that leads to economic growth of the Bangladesh incorporating time series data from year 1972 to year 2010.After data analysis, It is revealed that economic growth of the country positively attached with level of energy consumption keeping other variables constant. Moreover, FDI has affirmative impact on energy consumption in Bangladesh. However, this study limits with energy consumption irrespective to disaggregated sources like renewable and non-renewable energy that may stimulates potential idea for future research.

Bobde and Tanaka, 2018 [5], states that subsidies may result an inefficient management of power distribution utilities and privatized power distribution companies have proven them more efficient than private power distribution company. This study suggested that policy maker ought to be mindful that privatization may have variant effect on urban and rural areas for which they should consider geographical feature of the jurisdiction of power distribution. However, suggestion on findings limited to the countries with developing economy rapid urbanization not for other patterns of economy.

Shumais, [6] in their study which conducted on thirty diesel based power plant from Maldives as a sample organization attempting to measure technical efficiency of sample sector through the use of stochastic frontier analysis (SFA). The research aims to evaluate the level of ownership on power plant, use of resource, size, consumption of renewable energy by the power plant and its role on electricity sector. Findings of the study proclaim that, privately owned organization operates more efficiently than public organization irrespective to size of the organization.

Tavana [7], aims to illustrate the efficiency and productivity of factors of production and the output of the study proclaims that management resources like capital and energy are inefficient. Moreover, Investment fund is not sufficient to promote technology level up to bench mark level. Finally, this study advised the firm to replacement depreciating capital asset through increasing investment.

Jang [8], Self-governing power producers are more productive and profitable. In Contrast, they have higher cost of capital and holds high risk involves in market competitions compare with their counterparts.

Lin and Wang [9] this study made an assessment on energy productivity of chines energy sector by making some modification in production theory through decomposition method of output leaning energy. Again, inclusion of efficiency factor aims to visualize the extent at which energy productivity is influence by scale efficiency, management efficiency optimization and balanced development that helps producing insights into emission abatement and energy saving within industrial sector of china. Analysis of the result opened variation scenario of energy productivity tend and its contributing factors that facilitate identifying promoters and obstructers adjoining to 
improvement of industrial energy productivity and guide a road map to the local and central authority for future actions.

Sueyoshi and Goto [10] attempted to apply DEA method to evaluate the performance of electricity power companies in Japan, their business change and future direction during the year 2013 to 2020. Data from 2003 to 2015 and 2016 to 2020 are separately examined with unique characteristics of the data set. This is because, annual periods are more important to the policy maker because of nuclear disaster consequences more suffering for those companies under electric power industry sector.

Tavana et al., [7], applied DEA malmquist method efficiency, internal structure and productivity of nine Iranian oil refineries taking data from year 2015 to 2016.Findings of the study states there is inappropriate nature of management capacity prevailed while using resources specifically capital and energy. Moreover, up gradation of technology is ignored in investment strategy though depreciation rate of capital facilities are high in this sector. Finally, this research suggested that investment motive should concentrate on removal of depreciated capital.

Mahi et al., [11] assessed long term connectivity between financial development, economic growth and energy consumption considering time period of 1980-2017 from ASEAN-5 countries.Result of the study clams that there is no substantial impact among the variables in the long run.

Chai, Fan and Han, 2020 [12], applied a slacks-based data envelopment analysis (SBA-DEA) model to examine relations ship among price earnings ratio $(\mathrm{P} / \mathrm{E}$ ratio),industry status, and the level of improvement at technical efficiency by selecting seventeen companies of Chinese thermal power sector.The analysis of the study shows that the performance of energy efficiency can positively influence on the optimization of enterprises operation and $\mathrm{P} / \mathrm{E}$ ratio but clean-energy power generation is yet to improve their efficiency to gain better environmental benefits. Therefore, concerns should be aware to strike balance between efficiency and environmental sustainability.

\section{OBJECTIVE OF THE STUDY}

Several empirical studies have been conducted with a view to analysis the Total Factor Productivity (TFP) of energy and electricity sectors of different countries, especially in the developed countries. However, similar study yet to be conducted in context of Bangladesh power and energy sectors. Thus, this study has been done to find out this issue in the field of Bangladesh.

The objective of this study is to analyze the Total Factor Productivity (TFP) of power and energy sector in Bangladesh. To achieve this, we use a Data Envelopment Analysis (DEA) Malmquist approach worked on eleven privatized power and energy generating companies, taking time series data from year 2013 to 2019 (annual report of the selected companies).

\section{DATA AND METHODOLOGY}

The main aim of this study is to empirically explore the Total factor productivity TFP of power and Energy sector in Bangladesh. To achieve this objective, this study uses the annual time-series secondary data collected from various sources such as websites of Chittagong Stock Exchange (CSE), Dhaka Stock Exchange (DSE) and annual reports of those respective companies. Malmquist data Analysis method with output oriented under variable return to scale (VRS) was used to analyze data series taking into consideration of two inputs and three output variables.

In this section, we shall identify the methodology that is appropriate for our study. The study decides to employ panel data. We will address the data which are collected for the study and also mention the source of the data. And finally, a proper method will be selected to analyze the data in order to provide a conclusion on the Total factor productivity of power and energy in Bangladesh.

The study is based on the annual time-series secondary data sources. To conduct this study we have collected 2013 to 2019 about (07) years of data of selective power and generating and energy distribution companies. These companies are listed on two stock exchanges named, Dhaka Stock Exchange (DSE) as well as the Chittagong Stock Exchange (CSE).

Selected companies are;

i. Baraka Power Limited (BPL)

ii. CVO petrochemical Limited (CVOPL)

iii. Dhaka electricity Supply Company Limited (DESCO)

iv. Doreen Power Limited(DPL)

v. GBB power limited(GBBPL)

vi. Khulna Power Company Limited (KPCL)

vii. Meghna Petroleum Limited (MPL)

viii. Power Grid company limited (PGCL)

ix. Shahji Bazer Power Limited(SBPL)

x. Summit Power Limited(SPL) and

xi. Titas Gas distribution Limited (TGDL).

As DEA analysis is carried on using multiple input and output factors, our study considered the following factors to run our analysis; Output factors: Revenue and Net Income, Total Asset, Input factors: Operating Expense and Salary Expense.

\section{RESULTS}

5.1 Annual changes of Total factor productivity

Productivity analysis measure performance change of a company indicated by output variables with 
a given input variables. Therefore, our objective is to identify the productivity determinants of the power and energy sector in Bangladesh. We explain the overall productivity of the sample industry from 2013-2018.

Table-1: Analysis of factor productivity trend of Power and Energy sector of Bangladesh during the period of 2013 to 2018 (DEA: Malmquist)

\begin{tabular}{|l|l|l|l|l|l|}
\hline Year & $\begin{array}{l}\text { Efficiency } \\
\text { Change }\end{array}$ & $\begin{array}{l}\text { Technical efficiency } \\
\text { Change }\end{array}$ & $\begin{array}{l}\text { Pure efficiency } \\
\text { Change }\end{array}$ & $\begin{array}{l}\text { scale efficiency } \\
\text { change }\end{array}$ & $\begin{array}{l}\text { Total Factor productivity } \\
\text { change. }\end{array}$ \\
\hline 2014 & 1.079 & 0.880 & 1.043 & 1.034 & 0.949 \\
\hline 2015 & 1.356 & 0.840 & 0.991 & 1.368 & 1.140 \\
\hline 2016 & 0.999 & 0.991 & 1.052 & 0.949 & 0.990 \\
\hline 2017 & 0.571 & 1.624 & 0.953 & 0.599 & 0.927 \\
\hline 2018 & 1.031 & 1.103 & 0.987 & 1.045 & 1.138 \\
\hline
\end{tabular}

Table1 present trend of efficiency factors of privately owned power and energy industry and Figure 1 shows an assessment of overall TFP of power and energy industry in Bangladesh. The average total factor productivity growth of is $4.5 \%$ per annum. However, the scenario proclaims vulnerable trend of productivity of this industry over year 2013-2018. For example the TFP change progress was positively moved by $14 \%$ in year 2015 due to remarkable change of $35 \%$ in efficiency, and $36.8 \%$ Change in scale efficiency. Moreover in 2018, it revealed a positive growth of TFP by $13 \%$ because of $3.1 \%, 10.3 \%, 4.5 \%$ change in efficiency, technical efficiency and scale efficiency respectively. In contrast, Industry is experiencing negative growth in TFP by $5.1 \%, 1 \%$, and $7.35 \%$ during year 2014, 2016, and 2017 correspondingly.

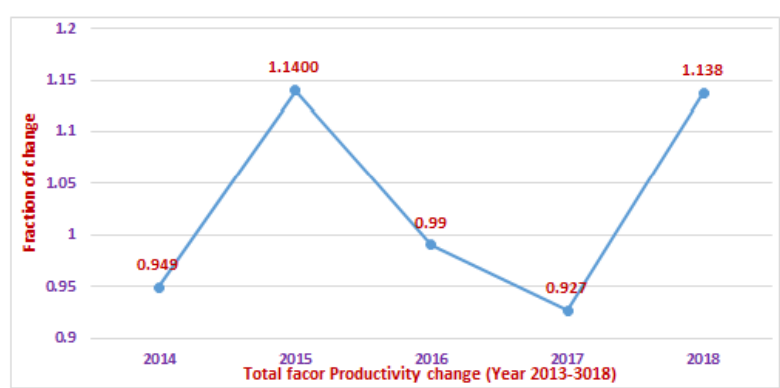

Fig-1: Trend analysis of TFP changes of power and energy production sector in Bangladesh (2013-2018)

Table-2: The Malmquist index summary of firm means of selected companies of CSE (2014-2018)

\begin{tabular}{|l|l|l|l|l|l|}
\hline Name of the Company & $\begin{array}{l}\text { Efficiency } \\
\text { Change }\end{array}$ & $\begin{array}{l}\text { Technical } \\
\text { efficiency } \\
\text { Change }\end{array}$ & $\begin{array}{l}\text { Pure } \\
\text { efficiency } \\
\text { Change }\end{array}$ & $\begin{array}{l}\text { scale } \\
\text { efficiency } \\
\text { change }\end{array}$ & $\begin{array}{l}\text { Total Factor } \\
\text { productivity } \\
\text { change }\end{array}$ \\
\hline Baraka Power Limited & 0.960 & 0.979 & 1.003 & 0.957 & 0.939 \\
\hline CVO petrochemical & 0.925 & 1.208 & 1.000 & 0.925 & 1.118 \\
\hline DESCO & 0.905 & 1.319 & 0.910 & 0.995 & 1.194 \\
\hline Doreen Power Limited & 1.000 & 1.032 & 1.000 & 1.000 & 1.032 \\
\hline GBB power limited & 0.892 & 0.998 & 1.048 & 0.851 & 0.890 \\
\hline KPCL & 1.000 & 1.199 & 1.000 & 1.000 & 1.199 \\
\hline Meghna Petrolium limited & 0.997 & 1.015 & 1.015 & 0.982 & 1.012 \\
\hline Power Grid company limited & 1.000 & 0.690 & 1.000 & 1.000 & 0.690 \\
\hline Shahji Bazer Power Limited & 1.093 & 0.961 & 1.081 & 1.011 & 1.050 \\
\hline Summit Power Limited & 1.052 & 1.163 & 1.000 & 1.052 & 1.224 \\
\hline Titas Gas distribution limited & 0.874 & 1.207 & 1.000 & 0.874 & 1.054 \\
\hline Mean Value & $\mathbf{0 . 9 7 0}$ & $\mathbf{1 . 0 5 6}$ & $\mathbf{1 . 0 0 4}$ & $\mathbf{0 . 9 6 6}$ & $\mathbf{1 . 0 2 5}$ \\
\hline
\end{tabular}

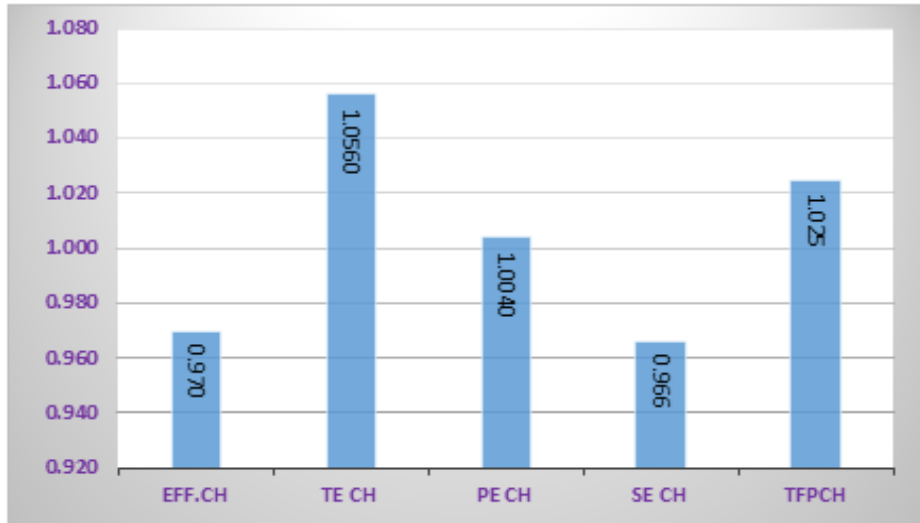

Fig-2: Average efficiency trend of power and energy producing companies 


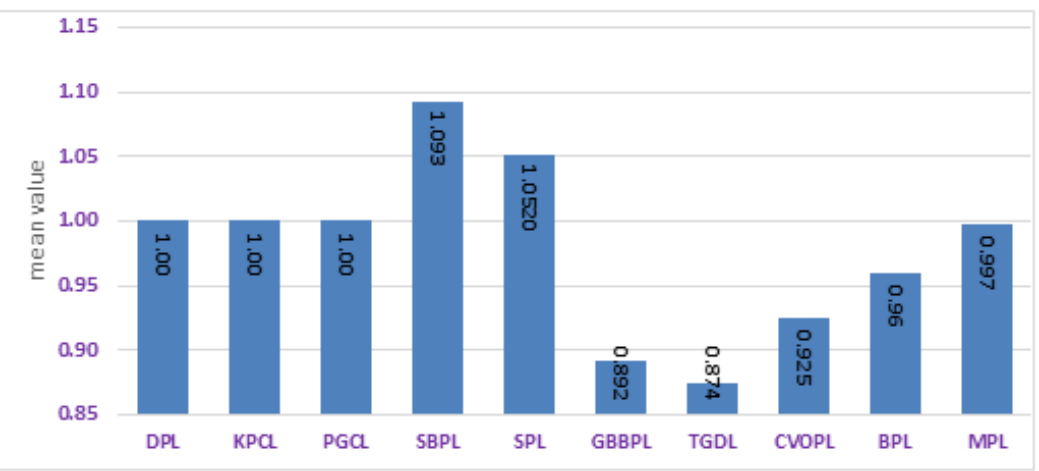

Fig-3: Firm wise average efficiency changes of selected companies

Efficiency change measures level of managerial efficiency of sample firm, involves with productivity change. From fig. 3, it is observed that summit power limited and shahji Bazer power limited are efficient in their management function but rest of the sample companies are yet to improve their efficiency in management functions.

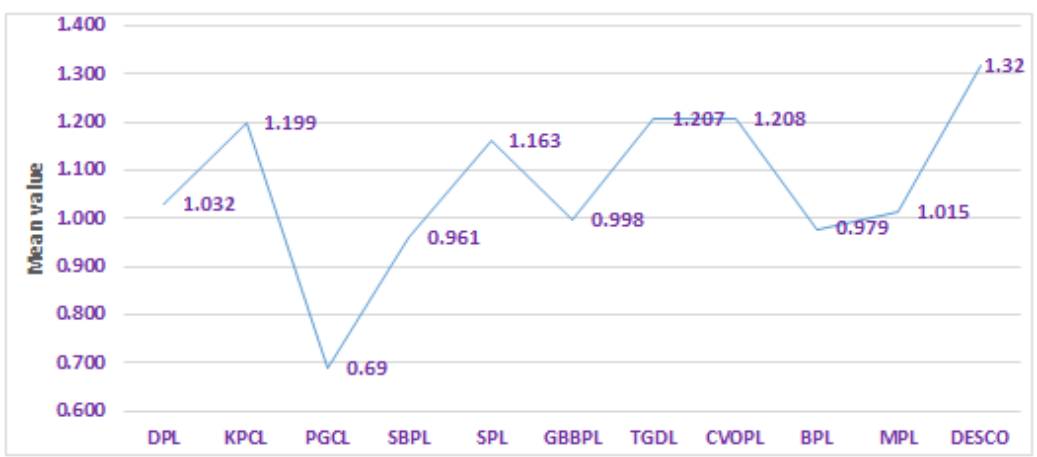

Fig-4: Technical efficiency change estimation of selected companies

A firm is treated as technically efficient if it can produce maximum output by using minimum quantity of inputs like capital, labor and technology. Fig.4, representing technical efficiency of selected firms in terms of average means value. The above graph states that DESCO power limited has gained highest technical efficiency among all companies though Doreen power limited, KPCL, Summit power limited,
Titas gas distribution, CVO petrochemical, Meghna petroleum have shown their technical efficiency performance. on the other hand companies like Power grid limited, Shahji bazar power limited, GBB power limited and Baraka power limited are yet to improve their efficiency in utilizing labor , capital and technology.

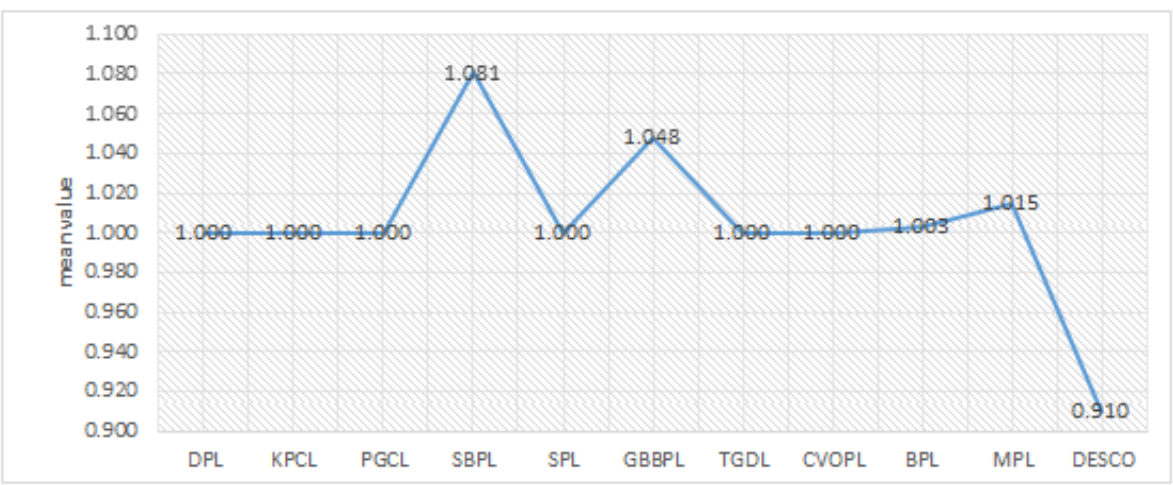

Fig-5: Company wise pure technical efficiency change from 2014 to 2018

Technical efficiency of power and energy companies is putrefied into pure technical efficiency along with scale efficiency. Pure technical efficiency measures firms' ability to produce certain amount output with a given amount of input i.e it measures firms level of capacity to save use of input in targeted amount production. The above fig.5, states that company shahji bazer power limited GBB power limited, meghna petroleum limited and Baraka power limited has improved their efficiency in utilizing input 
by $8.1 \%, 4.8 \% 1.5 \%$ and $.03 \%$ respectively. In contrast, rests of the firm are suggested to focus on enhancement of efficiency in input utilization so that they can save their cost of production.

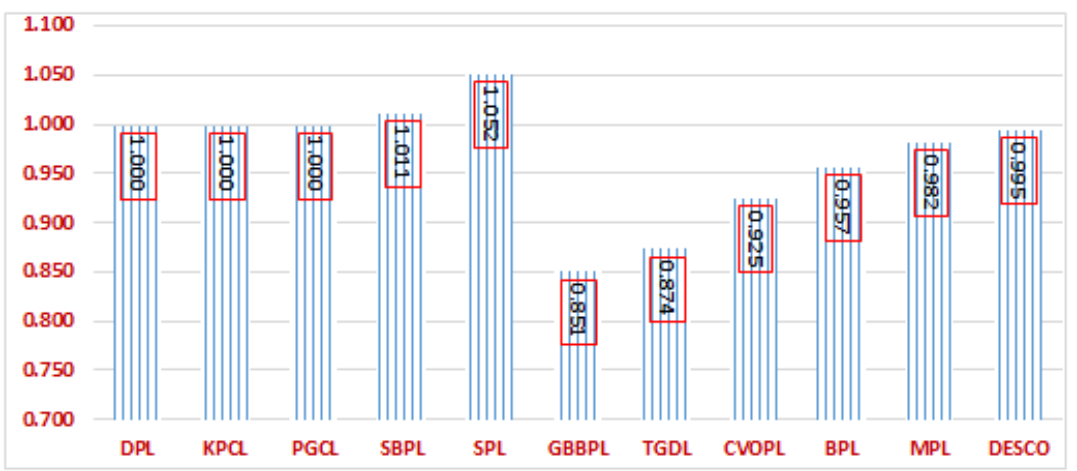

Fig-6: Firm wise average scale efficiency change in CSE

Figure 6 explain the scale of efficiency change of selected companies under Chittagong stock exchanged limited. Scale efficiency is a situation which enables firm to measure relationship between firms size with efficient use of input as a production factor Again, A firm is said to be scale efficient when a firm's size of operation is efficient and if we make any modification on its size it will be less efficient. Concentrating on our companies within sample period, the average scale efficiency of summit power and shaji Bazer power limited made a change of $5.2 \%$ and 1.15 positively. Conversely, Desco, meghna petroleum, Baraka power limited, CVO petrochemical, Titas gas GBB power limited are in inefficient position. Finally, rest of the companies has no change in improving of scale efficiency in production as their scale of efficiency lies with average value of 1 .

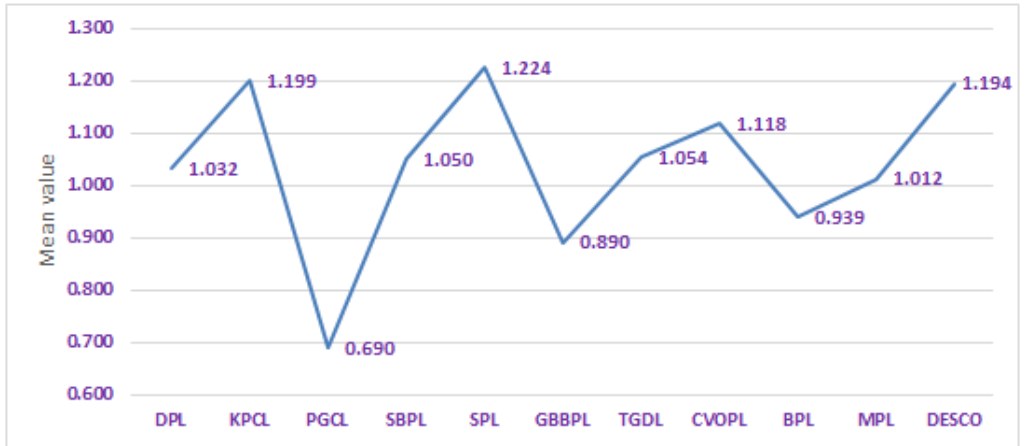

Fig-7: Total Factor productivity change of selected companies of CSE (2014-2018)

Total factor Productivity (TFP), is the measurement of firm's economic efficiency in production considering aggregate number of input and out-put factors at a given period of time. Hence, our productivity analysis was output oriented analysis, firms overall performance is measured through average value of total factor productivity change. Fig.7 states the productivity condition of eleven companies listed under Chittagong stock exchange, out of this Summited power limited is in highest position and power Grid Company is experiencing worst condition in their productivity. Moreover, a notable number of companies have shown overall performance in their productivity as their average value of total factor productivity is greater than one except Baraka power limited and GBB power limited.

\section{RECOMMENDATIONS AND CONCLUSION}

The current study examined efficiency, technical efficiency, pure technical efficiency along with scale efficiency as well as finally total factor productivity change of power and energy generating companies listed under Chittagong stock exchange limited. The mean value of total factor productivity of this industry is 1.025 means efficiency of this industry is increases by $2.5 \%$ from year 2013-2018 though yearly efficiency of was not satisfactory except 2015 and 2018. From Malmquist analysis, we found that this industry has less efficient management than its technical efficiency. Moreover scale efficiency is not in satisfactory condition though there is positive efficiency scenario in technical efficiency. Therefore, weak companies within this industry may rethink about increasing management efficiency and scale efficiency which will help to overcome inconsistency of efficiency in productivity. As the study limits within public 
limited companies under Chittagong stock exchange which failed to reflect overall performance of this sector in Bangladesh. Future research may be carried out considering both private and state owned organization to get real scenario of this sector that will contribute to economic development as well as to satisfy unbound demand of energy and electricity with efficiency and profitably in Bangladesh.

\section{REFERENCES}

1. Islam S, Khan MZ. A review of energy sector of Bangladesh. Energy Procedia. 2017 Mar 1; 110:611-8.

2. Ahamad MG, Islam AN. Electricity consumption and economic growth nexus in Bangladesh: Revisited evidences. Energy policy. 2011 Oct 1;39(10):6145-50.

3. Meibodi E. Efficiency Considerations in the Electricity Supply Industry: The Case of Iran (Doctoral dissertation, university of Surrey).

4. Khatun F, Ahamad M. Foreign direct investment in the energy and power sector in Bangladesh: Implications for economic growth. Renewable and Sustainable Energy Reviews. 2015 Dec 1; 52:136977.

5. Bobde SM, Tanaka M. Efficiency evaluation of electricity distribution utilities in India: A twostage DEA with bootstrap estimation. Journal of the Operational Research Society. 2018 Sep 2;69(9):1423-34.

6. SHUMAIS M. Resource Use Efficiency of Electricity Sector in the Maldives. The Journal of Asian Finance, Economics, and Business. 2020;7(1):111-21.

7. Tavana M, Khalili-Damghani K, Arteaga FJ, Hashemi A. A Malmquist productivity index for network production systems in the energy sector. Annals of Operations Research. 2020 Jan;284(1):415-45.

8. Jang H. Firm structure, scale economies, and productivity in the US electric power industry: A cost function analysis. Energy \& Environment. 2020 Nov 19:0958305X20971627.

9. Lin B, Wang M. How to boost energy productivity in China's industrial sector: An integrated decomposition framework based on multidimensional factors. Journal of Cleaner Production. 2020 Jun 20; 259:120902.

10. Sueyoshi T, Goto M. Performance assessment of Japanese electric power industry: DEA measurement with future impreciseness. Energies. 2020 Jan;13(2):490.

11. Mahi M, Phoong SW, Ismail I, Isa CR. Energyfinance-growth nexus in ASEAN-5 countries: an ARDL bounds test approach. Sustainability. 2020 Jan;12(1):5.

12. Chai J, Fan W, Han J. Does the Energy Efficiency of Power Companies Affect Their Industry Status? A DEA Analysis of Listed Companies in Thermal Power Sector. Sustainability. 2020 Jan;12(1):138.

\section{APPENDIX:}

\section{Results from DEAP Version 2.1}

Instruction file $=\mathrm{Eg} 3$-ins.txt

Data file = eg3-data.txt

Output orientated Malmquist DEA

\section{DISTANCES SUMMARY}

\begin{tabular}{|c|c|c|c|c|}
\hline \multirow{2}{*}{$\begin{array}{l}\text { firm } \\
\text { no. } \\
\text { t-1 }\end{array}$} & \multicolumn{4}{|c|}{$\begin{array}{l}\text { crs te rel to tech in } \mathrm{yr} \text { vrs } \\
* * * * * * * * * * * * * * * * * * * * * *\end{array}$} \\
\hline & $\mathrm{t}$ & $\mathrm{t}+1$ & & \\
\hline 1 & 0.000 & 0.339 & 0.324 & 0.360 \\
\hline 2 & 0.000 & 0.160 & 0.148 & 1.000 \\
\hline 3 & 0.000 & 0.587 & 0.469 & 1.000 \\
\hline 4 & 0.000 & 1.000 & 0.989 & 1.000 \\
\hline 5 & 0.000 & 0.421 & 0.539 & 0.789 \\
\hline 6 & 0.000 & 1.000 & 1.372 & 1.000 \\
\hline 7 & 0.000 & 0.358 & 0.323 & 0.811 \\
\hline 8 & 0.000 & 1.000 & 29.309 & 1.000 \\
\hline 9 & 0.000 & 0.634 & 0.854 & 0.677 \\
\hline 10 & 0.000 & 0.432 & 0.459 & 1.000 \\
\hline 11 & 0.000 & 0.275 & 0.251 & 1.000 \\
\hline
\end{tabular}

$\begin{array}{lllll}\text { Mean } \quad 0.000 \quad 0.564 & 3.185 & 0.876\end{array}$

Year $=2$

Firm crs te rel to tech in $\mathrm{yr}$ vrs
No. $\quad * * * * * * * * * * * * * * * * * * * * * * *$ te $\mathrm{t}-1 \quad \mathrm{t} \quad \mathrm{t}+1$

$\begin{array}{lcccc}1 & 0.367 & 0.429 & 0.503 & 0.444 \\ 2 & 0.240 & 0.310 & 0.223 & 1.000 \\ 3 & 0.701 & 0.565 & 0.869 & 1.000 \\ 4 & 1.068 & 0.992 & 2.197 & 1.000 \\ 5 & 0.291 & 0.389 & 0.388 & 0.617 \\ 6 & 1.311 & 1.000 & 2.495 & 1.000 \\ 7 & 0.328 & 0.288 & 0.395 & 0.904 \\ 8 & 0.809 & 1.000 & 1.037 & 1.000 \\ 9 & 2.916 & 1.000 & 1.058 & 1.000 \\ 10 & 0.431 & 0.409 & 0.529 & 1.000 \\ 11 & 0.250 & 0.244 & 0.483 & 1.000\end{array}$

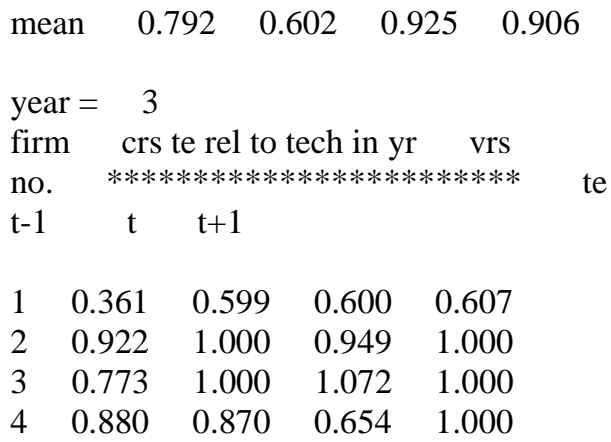


Mohammad Emdad Hossain et al., Sch J Econ Bus Manag, May, 2021; 8(5): 145-153

$\begin{array}{lcccc}5 & 0.279 & 0.293 & 0.255 & 0.433 \\ 6 & 2.079 & 1.000 & 1.082 & 1.000 \\ 7 & 0.327 & 0.442 & 0.350 & 0.853 \\ 8 & 1.087 & 1.000 & 1.380 & 1.000 \\ 9 & 2.459 & 1.000 & 4.344 & 1.000 \\ 10 & 0.515 & 0.622 & 0.510 & 1.000 \\ 11 & 0.242 & 0.565 & 0.555 & 1.000\end{array}$

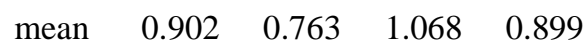

year $=4$

firm crs te rel to tech in yr vrs

no. $* * * * * * * * * * * * * * * * * * * * * * *$ te

$\mathrm{t}-1 \quad \mathrm{t} \quad \mathrm{t}+1$

$\begin{array}{lllll}1 & 0.513 & 0.519 & 0.345 & 0.523\end{array}$

$\begin{array}{lllll}2 & 0.975 & 0.949 & 0.236 & 1.000\end{array}$

$\begin{array}{lllll}3 & 1.165 & 1.000 & 0.228 & 1.000\end{array}$

$\begin{array}{lllll}4 & 1.029 & 0.817 & 0.920 & 1.000\end{array}$

$\begin{array}{lllll}5 & 0.277 & 0.271 & 0.258 & 1.000\end{array}$

$\begin{array}{lllll}6 & 1.098 & 1.000 & 1.285 & 1.000\end{array}$

$\begin{array}{lllll}7 & 0.407 & 0.334 & 0.405 & 0.750\end{array}$

$\begin{array}{lllll}8 & 0.931 & 1.000 & 1.171 & 1.000\end{array}$

$\begin{array}{lllll}9 & 0.673 & 1.000 & 1.222 & 1.000\end{array}$

$\begin{array}{lllll}10 & 1.755 & 1.000 & 1.435 & 1.000\end{array}$

$\begin{array}{lllll}11 & 0.652 & 0.641 & 0.152 & 1.000\end{array}$

$\begin{array}{lllll}\text { mean } & 0.861 & 0.776 & 0.696 & 0.934\end{array}$

year $=5$

firm crs te rel to tech in yr vrs

no. $* * * * * * * * * * * * * * * * * * * * * * * *$ te

$\mathrm{t}-1 \quad \mathrm{t} \quad \mathrm{t}+1$

$\begin{array}{lllll}1 & 0.226 & 0.242 & 0.221 & 0.392\end{array}$

$\begin{array}{lllll}2 & 0.075 & 0.069 & 0.060 & 1.000\end{array}$

$\begin{array}{lllll}3 & 1.224 & 0.282 & 0.284 & 1.000\end{array}$

$\begin{array}{lllll}4 & 1.303 & 1.000 & 0.912 & 1.000\end{array}$

$\begin{array}{lllll}5 & 0.248 & 0.232 & 0.202 & 1.000\end{array}$

$\begin{array}{lllll}6 & 8.656 & 1.000 & 1.004 & 1.000\end{array}$

$\begin{array}{lllll}7 & 0.308 & 0.307 & 0.267 & 0.592\end{array}$

$\begin{array}{lllll}8 & 1.037 & 1.000 & 0.851 & 1.000\end{array}$

$\begin{array}{lllll}9 & 1.093 & 1.000 & 1.298 & 1.000\end{array}$

$\begin{array}{lllll}10 & 4.625 & 1.000 & 0.961 & 1.000\end{array}$

$\begin{array}{lllll}11 & 0.696 & 0.146 & 0.128 & 1.000\end{array}$

$\begin{array}{lllll}\text { mean } & 1.772 & 0.571 & 0.563 & 0.908\end{array}$

year $=6$

firm crs te rel to tech in yr vrs

no. $* * * * * * * * * * * * * * * * * * * * * * * *$ te

$\mathrm{t}-1 \quad \mathrm{t} \quad \mathrm{t}+1$

$\begin{array}{lllll}1 & 0.321 & 0.276 & 0.000 & 0.365\end{array}$

$\begin{array}{lllll}2 & 0.124 & 0.108 & 0.000 & 1.000\end{array}$

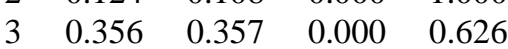

$\begin{array}{lllll}4 & 1.290 & 1.000 & 0.000 & 1.000\end{array}$

$\begin{array}{lcccc}5 & 0.278 & 0.238 & 0.000 & 1.000 \\ 6 & 1.136 & 1.000 & 0.000 & 1.000 \\ 7 & 0.412 & 0.353 & 0.000 & 0.875 \\ 8 & 1.206 & 1.000 & 0.000 & 1.000 \\ 9 & 1.233 & 0.990 & 0.000 & 1.000 \\ 10 & 0.554 & 0.556 & 0.000 & 1.000 \\ 11 & 0.159 & 0.140 & 0.000 & 1.000\end{array}$

$\begin{array}{lllll}\text { mean } & 0.642 & 0.547 & 0.000 & 0.897\end{array}$

[Note that $\mathrm{t}-1$ in year 1 and $\mathrm{t}+1$ in the final year are not defined]

\section{MALMQUIST INDEX SUMMARY}

year $=2$

firm effch techch pech sech tfpch

$\begin{array}{llllll}1 & 1.265 & 0.945 & 1.232 & 1.027 & 1.196\end{array}$

$\begin{array}{llllll}2 & 1.938 & 0.915 & 1.000 & 1.938 & 1.772\end{array}$

$\begin{array}{llllll}3 & 0.962 & 1.247 & 1.000 & 0.962 & 1.199\end{array}$

$\begin{array}{llllll}4 & 0.992 & 1.044 & 1.000 & 0.992 & 1.035\end{array}$

$\begin{array}{llllll}5 & 0.923 & 0.765 & 0.782 & 1.180 & 0.706\end{array}$

$\begin{array}{lllllll}6 & 1.000 & 0.977 & 1.000 & 1.000 & 0.977\end{array}$

$\begin{array}{llllll}7 & 0.803 & 1.124 & 1.115 & 0.721 & 0.903\end{array}$

$\begin{array}{llllll}8 & 1.000 & 0.166 & 1.000 & 1.000 & 0.166\end{array}$

$\begin{array}{llllll}9 & 1.577 & 1.471 & 1.478 & 1.067 & 2.320\end{array}$

$\begin{array}{llllll}10 & 0.947 & 0.995 & 1.000 & 0.947 & 0.943\end{array}$

$\begin{array}{llllll}11 & 0.887 & 1.059 & 1.000 & 0.887 & 0.939\end{array}$

$\begin{array}{llllll}\text { mean } & 1.079 & 0.880 & 1.043 & 1.034 & 0.949\end{array}$

year $=3$

firm effch techch pech sech tfpch

$\begin{array}{llllll}1 & 1.395 & 0.717 & 1.369 & 1.020 & 1.000\end{array}$

$\begin{array}{llllll}2 & 3.229 & 1.131 & 1.000 & 3.229 & 3.652\end{array}$

$\begin{array}{llllll}3 & 1.771 & 0.709 & 1.000 & 1.771 & 1.255\end{array}$

$\begin{array}{llllll}4 & 0.877 & 0.676 & 1.000 & 0.877 & 0.593\end{array}$

$\begin{array}{llllll}5 & 0.753 & 0.977 & 0.702 & 1.073 & 0.735\end{array}$

$\begin{array}{llllll}6 & 1.000 & 0.913 & 1.000 & 1.000 & 0.913\end{array}$

$\begin{array}{llllll}7 & 1.535 & 0.734 & 0.944 & 1.627 & 1.127\end{array}$

$\begin{array}{llllll}8 & 1.000 & 1.024 & 1.000 & 1.000 & 1.024\end{array}$

$\begin{array}{llllll}9 & 1.000 & 1.525 & 1.000 & 1.000 & 1.525\end{array}$

$\begin{array}{llllll}10 & 1.519 & 0.801 & 1.000 & 1.519 & 1.216\end{array}$

$\begin{array}{llllll}11 & 2.318 & 0.465 & 1.000 & 2.318 & 1.079\end{array}$

$\begin{array}{llllll}\text { mean } & 1.356 & 0.840 & 0.991 & 1.368 & 1.140\end{array}$

year $=4$

firm effch techch pech sech tfpch

$\begin{array}{llllll}1 & 0.866 & 0.993 & 0.861 & 1.006 & 0.860\end{array}$

$\begin{array}{llllll}2 & 0.949 & 1.041 & 1.000 & 0.949 & 0.987\end{array}$

$\begin{array}{llllll}3 & 1.000 & 1.042 & 1.000 & 1.000 & 1.042\end{array}$

$\begin{array}{llllll}4 & 0.940 & 1.294 & 1.000 & 0.940 & 1.216\end{array}$

$\begin{array}{llllll}5 & 0.927 & 1.081 & 2.308 & 0.402 & 1.003\end{array}$ 
$\begin{array}{llllll}6 & 1.000 & 1.007 & 1.000 & 1.000 & 1.007\end{array}$

$\begin{array}{llllll}7 & 0.756 & 1.240 & 0.879 & 0.860 & 0.938\end{array}$

$\begin{array}{llllll}8 & 1.000 & 0.821 & 1.000 & 1.000 & 0.821\end{array}$

$\begin{array}{llllll}9 & 1.000 & 0.394 & 1.000 & 1.000 & 0.394\end{array}$

$\begin{array}{llllll}10 & 1.608 & 1.464 & 1.000 & 1.608 & 2.353\end{array}$

$\begin{array}{llllll}11 & 1.135 & 1.018 & 1.000 & 1.135 & 1.155\end{array}$

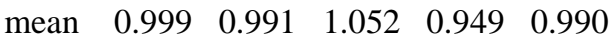

year $=5$

firm effch techch pech sech tfpch

$\begin{array}{llllll}1 & 0.467 & 1.183 & 0.749 & 0.624 & 0.553\end{array}$

$\begin{array}{llllll}2 & 0.073 & 2.085 & 1.000 & 0.073 & 0.152\end{array}$

$\begin{array}{llllll}3 & 0.282 & 4.357 & 1.000 & 0.282 & 1.230\end{array}$

$\begin{array}{llllll}4 & 1.223 & 1.076 & 1.000 & 1.223 & 1.316\end{array}$

$\begin{array}{llllll}5 & 0.857 & 1.058 & 1.000 & 0.857 & 0.907\end{array}$

$\begin{array}{llllll}6 & 1.000 & 2.596 & 1.000 & 1.000 & 2.596\end{array}$

$\begin{array}{llllll}7 & 0.918 & 0.910 & 0.789 & 1.163 & 0.835\end{array}$

$\begin{array}{llllll}8 & 1.000 & 0.941 & 1.000 & 1.000 & 0.941\end{array}$

$\begin{array}{llllll}9 & 1.000 & 0.945 & 1.000 & 1.000 & 0.945\end{array}$

$\begin{array}{llllll}10 & 1.000 & 1.796 & 1.000 & 1.000 & 1.796\end{array}$

$\begin{array}{llllll}11 & 0.228 & 4.489 & 1.000 & 0.228 & 1.022\end{array}$

$\begin{array}{llllll}\text { mean } & 0.571 & 1.624 & 0.953 & 0.599 & 0.927\end{array}$

year $=6$

firm effch techch pech sech tfpch

$\begin{array}{llllll}1 & 1.139 & 1.129 & 0.932 & 1.222 & 1.285\end{array}$

$\begin{array}{llllll}2 & 1.566 & 1.148 & 1.000 & 1.566 & 1.798\end{array}$

$\begin{array}{llllll}3 & 1.265 & 0.996 & 0.626 & 2.022 & 1.259\end{array}$

$\begin{array}{llllll}4 & 1.000 & 1.189 & 1.000 & 1.000 & 1.189\end{array}$

$\begin{array}{llllll}5 & 1.023 & 1.158 & 1.000 & 1.023 & 1.185\end{array}$

$\begin{array}{llllll}6 & 1.000 & 1.063 & 1.000 & 1.000 & 1.063\end{array}$

$\begin{array}{llllll}7 & 1.153 & 1.157 & 1.479 & 0.780 & 1.334\end{array}$

$\begin{array}{llllll}8 & 1.000 & 1.190 & 1.000 & 1.000 & 1.190\end{array}$

$\begin{array}{llllll}9 & 0.990 & 0.980 & 1.000 & 0.990 & 0.969\end{array}$ $\begin{array}{llllll}10 & 0.556 & 1.018 & 1.000 & 0.556 & 0.566 \\ 11 & 0.959 & 1.136 & 1.000 & 0.959 & 1.089\end{array}$

$\begin{array}{llllll}\text { mean } & 1.031 & 1.103 & 0.987 & 1.045 & 1.138\end{array}$

MALMQUIST INDEX SUMMARY OF ANNUAL MEANS

year effch techch pech sech tfpch

$\begin{array}{llllll}2 & 1.079 & 0.880 & 1.043 & 1.034 & 0.949\end{array}$

$\begin{array}{lllllll}3 & 1.356 & 0.840 & 0.991 & 1.368 & 1.140\end{array}$

$\begin{array}{llllll}4 & 0.999 & 0.991 & 1.052 & 0.949 & 0.990\end{array}$

$\begin{array}{llllll}5 & 0.571 & 1.624 & 0.953 & 0.599 & 0.927\end{array}$

$\begin{array}{llllll}6 & 1.031 & 1.103 & 0.987 & 1.045 & 1.138\end{array}$

$\begin{array}{llllll}\text { mean } & 0.970 & 1.056 & 1.004 & 0.966 & 1.025\end{array}$

MALMQUIST INDEX SUMMARY OF FIRM MEANS

firm effch techch pech sech tfpch

$\begin{array}{llllll}1 & 0.960 & 0.979 & 1.003 & 0.957 & 0.939\end{array}$

$\begin{array}{llllll}2 & 0.925 & 1.208 & 1.000 & 0.925 & 1.118\end{array}$

$\begin{array}{llllll}3 & 0.905 & 1.319 & 0.910 & 0.995 & 1.194\end{array}$

$\begin{array}{llllll}4 & 1.000 & 1.032 & 1.000 & 1.000 & 1.032\end{array}$

$\begin{array}{llllll}5 & 0.892 & 0.998 & 1.048 & 0.851 & 0.890\end{array}$

$\begin{array}{llllll}6 & 1.000 & 1.199 & 1.000 & 1.000 & 1.199\end{array}$

$\begin{array}{llllll}7 & 0.997 & 1.015 & 1.015 & 0.982 & 1.012\end{array}$

$\begin{array}{lllllll}8 & 1.000 & 0.690 & 1.000 & 1.000 & 0.690\end{array}$

$\begin{array}{llllll}9 & 1.093 & 0.961 & 1.081 & 1.011 & 1.050\end{array}$

$\begin{array}{llllll}10 & 1.052 & 1.163 & 1.000 & 1.052 & 1.224\end{array}$

$\begin{array}{llllll}11 & 0.874 & 1.207 & 1.000 & 0.874 & 1.054\end{array}$

$\begin{array}{llllll}\text { mean } & 0.970 & 1.056 & 1.004 & 0.966 & 1.025\end{array}$

[Note that all Malmquist index averages are geometric means] 